\title{
Potential and Implementation of Halal Tourism During the Covid-19 Pandemic in Semarang City
}

\author{
Muhammad Hermintoyo ${ }^{1 *}$, Nur Fauzan ${ }^{1}$, Alvina Maghfiroh ${ }^{1}$ \\ ${ }^{1}$ Faculty of Humanities, Diponegoro University, Semarang - Indonesia
}

\begin{abstract}
Semarang is an attractive and quite a lot of tourist destinations. This shows that the city of Semarang has potential in the implementation of tourism. In general, the tourism potential in the city of Semarang can be divided into natural tourism and cultural tourism. Tourism in the city of Semarang is feasible to implement halal tourist destinations. The definition of halal does not refer to religious or religious tourism but provides comfort for tourists who are predominantly Muslim. Halal tourism has been launched by the MUI since 2015. This declaration is expected to balance the implementation of halal tourism because the majority of the population is Muslim. Tourism potential During the COVID-19 pandemic, halal tourism in Semarang City, must comply with strict health protocols if tourism in Semarang City is to be opened. Data collection in this halal tourism research. Using the observation method with direct interview techniques and questionnaires via online / WA. The classified data is then analyzed qualitatively.
\end{abstract}

\section{Introduction}

Semarang is a city in Central Java that continues to improve in tourism development. The concept of tourism is not only natural tourism but as a city park and cultural tourism. This is following the potential of the city of Semarang as a tourist destination that has capital in that direction. As natural tourism there are Marina Beach, Reservoir and Kreo Cave, Maero Koco Park; as a city park tourism, there is Simpanglima Park, KB Park, Warak Park; as cultural tourism, many relics of cultural elements, such as old city buildings depicting ancient technology, Tugumuda, Lawang Sewu, Dutch-era school buildings; religious elements, such as Sampo Khong Temple building, Vihara, Kauman Mosque, Central Java Great Mosque; culinary that offers in addition to food also prepares a location to take pictures of nature and look around antiques, such as Kampung Laut, Ikan Bakar Cianjur Restaurant; culinary tour with typical Semarang, such as Soto Bangkong, chicken rice Mbak Tum; typical souvenirs of Semarang, such as wingko babad, spring rolls, bandeng presto, bread ganjel rel and various kinds of food in angkringan or organized place. Not to mention art tours, such as wayang kulit performances, wayang orang, ketoprak in Ki Narto Sabdo building, art performances and exhibitions at Raden Saleh Cultural Park and KB Park.

* Corresponding author: hermintpujangga@gmail.com 
Semarang City Government has a routine plan every year to bring local tourists and outside the city of Semarang, namely organizing a celebration of Semarang birthday art, lantern party on the West Canal Flood bridge, the celebration of the beginning of fasting known as Dugderan. This activity must be preserved because it provides a connoisseur for tourists [1].

This potential is an opportunity to attract local and foreign tourists (tourists stay in Indonesia 24 days to 1 year, and excursionists remain in Indonesia for less than 24 hours). In the source, Semarang City Statistics Agency reads about tourism [2]. The city government has also prepared facilities and pre-retirement, such as road repairs and transportation. The city is in tata and given a beautiful garden and accessories. Suppose the night looks even more beautiful with a light garden. The old buildings were restored and added gardens and lamps; the place is clean, there is a parking lot, and safe. This tourism potential is also prepared with the growth of motels, hotels, restaurants that certainly provide comfort and convenience for local tourists outside Semarang and abroad. Places of worship are also found especially for Muslims.

Because the majority of Indonesia's population is majority Muslim obviously if tourism in Semarang implements halal tourism. The definition of halal tourism is that tourism, in general, is only equipped with a place of worship for prayer [3], prepared mukenah, prayer mats, separate ablution places between women and men, urine places or restrooms are also separated between men and women, the water is clean, food sold halal, no liquor, no place of prostitution, providing services do not discriminate other than nonmuslim, there is no radical impression.

In the implementation at the location, some tourist sites that do not provide adequate prayer places, smelly water, urine places are not separated between men and women. In swimming, places are not separated between men and women. But in general, tourist sites provide a place of prayer; there is a separate place of ablution. For prayer mats and mukenah in general, the female tourists bring their own and consider more hygienic.

Halal tourism does not mean tourism for Muslims only, not religious tourism, such as pilgrimage, grand recitation but tourism that can be enjoyed by all Muslims and nonmuslim [4]. The point is the concept of halal tourism there is the comfort of morning tourists. Comfortable in enjoying the mood, the heart; give a good and beautiful impression. Furthermore, tourists will comeback again or promote to others, relatives, acquaintances to date to Semarang, which is full of charm as a halal tourist destination.

In the year of pandemic season Covid-19, tour managers in Semarang have concerns about whether it needs to be opened or closed. Tours can be opened, but there must be a rule of health protocol, namely limited visitors, prepared hand washing and soap, wearing masks, conducted swab tests. Of course, this needs extra work to run the rules of the health protocol. In general, tourists obey it, but one/ two people do not attend. However, he was reprimanded for obedience. In the pandemic season Covid-19, some places are not so crowded visited; there are one/two places that if the night is crowded connoisseurs, namely the old city and Simpang Lima (especially Sunday night). The culinary vendors in tourist sites most of its revenues slumped to $75 \%$ even many of its stalls were closed. The concept of tourism that should generate income in the economic sector becomes stalled [4]. Some culinary are still crowded, namely Mbak Tum chicken rice culinary, which is still crowded with connoisseurs. The visitors are not only Semarang residents but from outside the city, especially from Jakarta. In the early days of Covid-19, there was a ban on sales with restrictions on sales hours, making revenues slump. In 1921 it began to improve its consumers by implementing sales hours that were somewhat night and complying with health protocols [5].

\section{Research Method}


This study uses observation methods to several tourist sites in Semarang. Furthermore, to get the data conducted interviews with some tourists who are in tourist sites. To capture diverse data from the city of Semarang also outside the city of Semarang conducted with questionnaires online with at least 100 respondents. The data is then classified according to research purposes and qualitatively descriptively analyzed..

\section{Results and Discussion}

\subsection{Semarang Tourism Potential that is often visited}

\subsubsection{Cultural Tourism (buildings, cents, city parks, culinary etc.)}

The results of data from questionnaire and interviews directly, in general respondents visited various tourist sites in Semarang, favorite tourist attractions in the Old City indirectly around which there are tourist folders and ancient stations Tawang, Berok bridge, Semarang museum, and Post Office. Furthermore, Lawang Sewu, which is adjacent to the TNI Museum and Tugu Muda; park tourism in Simpang Lima, which is adjacent to KB Park, Raden Saleh Cultural Park, Narto Sabdo Art Building which on a certain schedule there is a performance of wayang kulit, wayang orang, ketoprak, traditional arts. Not to be missed enjoying the art festival around the Governor of Central Java and enjoying culinary and souvenirs typical of Semarang, such as bandeng presto, Mbak Tum chicken rice, Bangkong soup, spring rolls, wingko and ganjel rel bread, etc. All of these are cultural products with various elements.

\subsubsection{Nature Tourism}

Semarang city is geographically near the north sea, which has the potential as a natural tourist beach known as Marina Beach. Includes Maerokoco Park and Kampung Laut restaurant by taking place on the beach. The location is designed for taking pictures as well as the natural connoisseur of beautiful beaches.

\subsubsection{Semarang Tourist Destination Information}

Based on information from the Department of Culture and Tourism of Semarang [6], the largest majority of Muslims 1,470,442; Protestant 116,744; Catholic 86,166; Buda 10,894; Hinduism 1,238; other 427. Based on the research data, most respondents were Muslim, $76.7 \%$ the rest from various other religions. So it is not surprising that in Semarang, there is religious tourism known in the Semarang environment and outside the city even abroad, such as the existence of Semarang grand mosque, Buda Temple in Watu Gong, Sampo Kong Temple, and other small temples. The celebration welcomes the beginning of Ramadan with dugderan event.

\subsection{Semarang Tourist Destination Information}

Based on research data, Semarang tourist destination information is obtained through googling $56.4 \%$, social media $60.2 \%$, friend recommendations $45.6 \%$, media time $20.4 \%$, tour operators $8.7 \%$. Tourist destination information can be done by installing baleho in strategic places, books such as Raffiendie made entitled Semarang Culinary and Hangout. 
Information indirectly through the enjoyment of song lyrics, such as the work of Didik Kempot campursari musicians.

\subsection{Application of Semarang Tourism During the Pandemic}

The number of tourists coming to Semarang is seen from 2017-2020 based on the Department of Culture and Tourism of Semarang City [6]. There is a decrease due to the covid 19 pandemic in 2020. This can be seen from the following table:

Table 1. Number of tourists who come to Semarang in 2017-2020

\begin{tabular}{|c|c|c|c|c|}
\hline Year & $\mathbf{2 0 1 7}$ & $\mathbf{2 0 1 8}$ & $\mathbf{2 0 1 9}$ & $\mathbf{2 0 2 0}$ \\
\hline Domestic & 4.927 .960 & 5.703 .282 & 7.223 .529 & 3.260 .303 \\
\hline Overseas & 59.120 & 66.105 & 82.305 .559 & 6.628 \\
\hline
\end{tabular}

Based on observations in some tourist attractions in Semarang in 2021, tourists who come a little, only in the Old City are still many visitors, especially teens.

The application of health protocols in all tourism in Semarang is applied, such as clean water and soap as hand washing, wearing masks (one / two tourists do not wear but reprimanded by the tour manager, there is Swab except in Kota Lama tourism because of its location related to the flow of public traffic. Water is not good-smelling [7].

Based on research data, respondents agreed 53.4\% opened tourism in Semarang during the pandemic covid 19 who disagreed $46.6 \%$. The implementation of health protocol implementation in tourist attractions in Semarang has been implemented correctly: it has been implemented $30.1 \%$, not implemented $69.9 \%$.

\subsection{Halal Tourism Concept}

The Vice President's staff, Guntur Subagyo Mahardika, stated that halal tourism is a Muslim-friendly tourism ecosystem with excellent service and carries ethical value. While Gita Amanda [8] explained that halal tourism is an alternative option substantially carrying aspects of health, cleanliness, and environmentally friendly Cheriatna (2018: 31) by taking the opinion of Shahid [9], halal tourism is part of the tourism industry aimed at Muslim tourists whose services refer to Islamic rules. The goal is for Muslim tourists to get the needs of youth, and comforts, such as the availability of prayer places, clean water for ablution, urine places distinguished for women with men, the provision of mukenah, and clean prayer mats. There is a halal food certificate, no liquor, a clean place; there is a separator in the pool between men and women. The place is clean. There are certain instructions for Muslims and non-Muslims. So what is meant by halal tourism? In general, tourism is only added to the needs of prayer, ablution, and urination, which is separated between men and women and clean and comfortable. Rodame (2020) [10] stated halal tourism is not an exclusive tour because nonmuslim tourists can also enjoy services that are given a touch of Islamic values.

Based on research data on Halal Tourism knowledge, it was found that respondents heard the term halal tourism $68.9 \%$ while those who never heard $31.1 \%$ heard this term through electronic media and masa, also in social media. Respondents who knew the concept of halal tourism $57.3 \%$ and who did not know $42.7 \%$. This relates to respondents' answers about halal tourism, whether it is the same as religious tourism. Halal tourism is not the same as religious tourism $74.8 \%$ while stating yes, $25.2 \%$. Similarly, respondents who stated halal tourism is not a Muslim-only tour $78.6 \%$ while who answered $21.4 \%$ yes. The agreed concept of halal tourism is applied in Semarang, which states agree $97.1 \%$ 
while the disapproval $2.9 \%$. Based on the respondent's statement, it can be said that halal tourism can be carried out in Semarang city tourism, considering the majority of Semarang residents in particular and in Indonesian society, in general, are Muslims.

\section{Conclusion}

Based on the discussion above, the city of Semarang as a destination city, judging by its geographical location, has a lot of cultural and natural tourism potential. The majority of Semarang residents and, in general, Muslim tourists, so that there is comfort for tourists, need halal tourism. The definition of halal tourism is meant by tourism as in general only plus prayer place, clean water for ablution, toilets, swimming pools separated between men and women, halal cuisine, no liquor, no radical impression. Halal tourism, if during the covid 19 pandemic is opened, requires strict implementation of health protocols, and certain restrictions must be adhered to by managers and tourists. In general, respondents responded well if tourism in Semarang implemented halal tourism and opened during the covid 19 pandemic. The potential and implementation of halal tourism has been implemented by improving, renovating, and enforce health protocols at all tourist sites.

\section{References}

1. Interview with Dinas Kebudayaan dan Pariwisata Kota Semarang, (Mei 2021).

2. Dinas Kepemudaan, Olahraga dan Pariwisata Propinsi Jawa Tengah, Draft Buku Pariwisata Jawa Tengah dalam Angka, (2020).

3. Deputi Bidang Pengembangan Industri dan Kelembagaan Pariwisata, Panduan Penyelenggaraan Pariwisata Halal. Jakarta: Kementrian Pariwisata. Page3 (2019)

4. Betty Selfia Ayu Utami \&Abdullah Kafabihi, "Sektor Pariwisata Indonesia di Tengah Pandemi Covid 19". Jurnal Dinamika Ekonomi dan Pembangunan, 4(1),383-389. (2021).

5. Interview with Mbak Tum (Mei 2021).

6. Dinas Kebudayaan dan Pariwisata Kota Semarang/ Cultur and Tourism of Semarang Municipality (2020).

7. Interview with old city tour guide.

8. Gita Amanda, Pariwisata Halal Potensial Dikembangkan di Tengah Pandemi, (26 Mei, 2021) Retried from: Republika.co.id

9. Cheriatna, Laris Manis Bisnis Wisata Halal. Gema Insani Depok, Jakarta (2018).

10. R.M. Napitupulu, Wisata Halal, PT Jawa Mediasindo Bogor (2020). 